\title{
Pengaruh Penambahan Oksidatoor Pada Proses Pelindian Oksidatif Konsentrat Galena
}

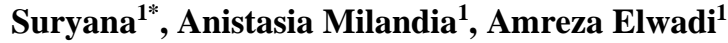 \\ ${ }^{1}$ Teknik Metalurgi, Universitas Sultan Tirtayasa, Cilegon, 42435, Indonesia \\ *suryana@untirta.ac.id
}

\begin{abstract}
Abstrak
Kebutuhan logam timbal di dalam negeri saat ini masih cukup besar, namun tidak diimbangi dengan kemampuan industri pemurnian timbal domestik. Sumber daya bijih timbal yang tersedia di Indonesia cukup besar sehingga memberikan peluang untuk pembangunan proses pengolahan timbal. Proses pemurnian timbal baik dari sumber mineral maupun daur ulang dari komponen aki bekas hingga saat ini umumnya menggunakan jalur pirometalurgi yang memberikan dampak buruk pada lingkungan, sehingga jalur hidro-elektro metalurgi menjadi solusi. Penelitian ini mencakup pemurnian timbal melalui proses hidrometalurgi dengan melakukan pelindian oksidatif konsentrat galena dalam media asam flosilikat dengan menggunakan oksidator berupa hidrogen peroksida dan timbal oksida $\left(\mathrm{PbO}_{2}\right)$ dari katoda aki bekas . Penentuan parameter operasi pelindian seperti fraksi ukuran partikel konsentrat galena, jumlah penambahan oksidator $\mathrm{PbO}_{2}$ dari katoda aki bekas, kecepatan agitasi, temperatur pelindian, dan persentase padatan operasi pelindian dilakukan untuk menekan konsumsi reagen sehingga dicapai proses pelindian yang efisien. Pada penelitian ini dilakukan proses pelindian dengan memvariasikan penambahan Oksidator $\mathrm{PbO}_{2}$ dari katoda aki bekas sedangkan parameter lain pada kondisi konstan. Hasil pelindian menunjukkan bahwa persen ekstraksi timbal tertinggi diperoleh dengan melakukan pelindian pada penambahan oksidator $\mathrm{PbO}_{2}$ sebanyak 1,5 kali basis stoikiometri.
\end{abstract}

Katakunci: oksidator $\mathrm{PbO}_{2}$, pelindian oksidatif, galena, stoikiometri

\section{Pendahuluan}

Timbal masih menjadi salah satu komoditas logam non-ferrous yang utama dalam industri modern. Sifat timbal memiliki ketahanan korosi yang baik, keuletan yang tinggi serta mampu menahan radiasi [1]. Luasnya aplikasi timbal di bidang manufaktur menyebabkan tingginya permintaan logam timbal di dalam negeri. Kebutuhan akan logam timbal di dalam negeri tidak diimbangi dengan kemampuan industri pemurnian timbal domestik untuk menjawab tantangan tersebut, sehingga untuk saat ini, Indonesia masih menggunakan timbal impor untuk memenuhi permintaan logam timbal dalam negeri. Berdasarkan data statistik dari BPS tahun 2016, Indonesia masih mengimpor logam timbal sebesar 117.148,9 ton. Angka impor tersebut didominasi oleh tiga penggunaan timbal pada industri seperti kebutuhan konstruksi yang mencakup plumbing dan pipa minyak dan air sebesar 13\%, industri pembuatan baterai, akumulator dan elektroda sel elektrolisa sebesar $86 \%$ [2].

Indonesia memiliki potensi sumber daya bijih timbal yang besar. Sumber utama logam timbal adalah mineral galena $(\mathrm{PbS})$. Berdasarkan data statistik mineral dan batubara yang dihimpun dari Badan Geologi tahun 2015, sumber daya bijih timbal yang tersedia di Indonesia adalah sebesar 401.218.565,6 ton dengan cadangan sebesar 11.494.090,9 ton [3]. Melimpahnya sumber daya mineral logam timbal dan merujuk pada regulasi yang ada, pembangunan industri berbasis hilirisasi logam timbal dapat menjawab kebutuhan akan logam timbal di dalam negeri. Mengingat profil logam timbal sebagai logam berat yang sangat berbahaya bagi kesehatan, pemilihan proses pengolahan galena yang ramah lingkungan dan efisien perlu diperhatikan. Proses pemurnian timbal baik dari sumber mineral maupun daur ulang dari aki bekas saat ini umumnya menggunakan jalur pirometalurgi. Proses pemurnian galena yang merupakan senyawa sulfida, harus melewati proses pemanggangan (roasting) yang mengubah senyawa sulfida menjadi senyawa oksida agar memudahkan reduksi guna mendapatkan logam timbal. Proses pemanggangan mineral sulfida menyebabkan terbentuknya emisi gas $\mathrm{SO}_{2}$ di lingkungan. 
Konsentrasi gas $\mathrm{SO}_{2}$ yang pekat di udara dapat menyebabkan hujan asam. Hasil perhitungan neraca massa menunjukkan bahwa pemurnian logam timbal dari galena dengan jalur pirometalurgi menghasilkan $308 \mathrm{~kg}$ gas $\mathrm{SO}_{2}$ per ton logam timbal yang dihasilkan. Aktualnya jumlah $\mathrm{SO}_{2}$ yang terbentuk dipengaruhi oleh kondisi reaksi, terutama suhu dan bervariasi dari 1 sampai $10 \%$ dari total $\mathrm{SO}_{2}$ [4]. Berdasarkan statistik BLH tahun 2010, sektor industri menghasilkan gas $\mathrm{SO}_{2}$ sebanyak 250 kilo ton per tahun. Hal ini menunjukkan bahwa apabila dibangun perusahaan pemurniaan timbal berbasis pirometalurgi di Indonesia, gas $\mathrm{SO}_{2}$ akan bertambah sebesar $6 \%$ dalam rangka memenuhi kebutuhan timbal di dalam negeri per tahun. Oleh karena itu, pemurnian galena dengan jalur pirometalurgi dianggap tidak ramah lingkungan. Taufik (2015), melaporkan bahwa pada tahun 2015, tercatat lebih dari 200 praktik peleburan aki bekas dilakukan di Indonesia dengan 71 tempat berlokasi berdekatan dengan Jakarta yang memiliki 20 juta penduduk di dalamnya [5]. Profil timbal sebagai logam berat menyebabkan terbentuknya debu timbal produk leburan yang terbawa bersama gas buang yang sangat berbahaya apabila terhirup oleh makhluk hidup [6].

Proses pemurnian timbal dengan menggunakan jalur hidro-elektro metalurgi dapat menjadi solusi mengingat proses ini tidak menghasilkan emisi gas $\mathrm{SO}_{2}$ yang berujung pada konservasi lingkungan [7]. Lee dkk (1986) menyebutkan dalam penelitiannya telah mendapatkan persen ekstraksi sebesar 96\% dengan melakukan pelindian galena pada media pelindi asam flosilikat, dengan oksidator berupa hidrogen peroksida dan $\mathrm{PbO}_{2}$ [8]. Amalia dkk (2017) dalam penelitiannya mendapatkan persen timbal sebesar 66,59\% dalam pelindian galena dengan menggunakan asam flosilikat dan hidrogen peroksida sebagai oksidator. Jumlah penggunaan reagen adalah 2 kali basis stoikiometri dengan fraksi ukuran $-325 \#$ pada temperatur $90^{\circ} \mathrm{C}$ [9]. Anugrah dkk (2017), dalam penelitiannya melaporkan bahwa pelindian galena pada media asam flosilikat dengan menggunakan hidrogen peroksida dapat dilakukan dengan baik yang menghasilkan persen ekstraksi sebesar $99 \%$ dengan temperatur pelindian $97^{\circ} \mathrm{C}$, kecepatan agitasi $300 \mathrm{rpm}$, persen padatan $12 \%$, dan ukuran partikel $-100+150 \#$. Namun, konsumsi asam flosilikat sebagai media pelindi masih tinggi yaitu sebesar 3 kali basis stoikiometri [10].

Penggunaan reagen merupakan salah satu pertimbangan utama dalam perancangan proses. Jumlah reagen berkaitan dengan biaya produksi, sehingga perilaku oksidasi pada proses pelindian galena menjadi hal yang penting untuk diteliti. Dengan perancangan penelitian yang tepat (perancangan proses yang efisien dan optimum) diharapkan pengolahan timbal yang efektif dan efisien dapat tercapai.

\section{Bahan}

Bijih mineral yang digunakan merupakan konsentrat galena hasil konsentrasi flotasi dari kecamatan Cigudeg, kabupaten Bogor, Jawa Barat. Hasil karakterisasi bijih mineral menunjukkan mineral-mineral utama berupa galena $(\mathrm{PbS})$, kalkopirit $\left(\mathrm{CuFeS}_{2}\right)$, dan spalerit $(\mathrm{ZnS})$. Ukuran konsentrat galena yang digunakan sebesar $-200+325 \#$.

\section{Metode}

Proses pelindian dilakukan pada suatu reaktor berbahan Teflon dengan media pelindi yang digunakan asam flosilikat $\left(\mathrm{H}_{2} \mathrm{SiF}_{6}\right)$. Proses pelindian dilakukan pada hot plate magnetic dengan kecepatan agitasi konstan yaitu sebesar $300 \mathrm{rpm}$. Pemberian oksidator $\mathrm{H}_{2} \mathrm{O}_{2}$ dan $\mathrm{PbO}_{2}$ dilakukan setiap 15 menit dengan variasi penambahan $\mathrm{PbO}_{2}$ sebesar 0,5-2 kali stoikiometri. Proses pelindian dilakukan selama 150 menit. Proses pelindian dilengkapi dengan kondensor untuk mencegah perubahan persen padatan pada proses pelindian. Skema alat proses pelindian ditunjukkan pada Gambar 1. Hasil pelindian disaring menggunakan vacuum filter sehingga residu yang tidak larut tertahan pada kertas saring. Dekantasi dilakukan pada residu dengan cara membilas residu menggunakan aquades hingga $\mathrm{pH}$ residu netral. Analisa kandungan logam terlarut pada filtrat hasil pelindian dilakukan dengan instrument AAS tipe AA 240 FS. Indentifikasi senyawa yang 
terkandung pada residu yang tertahan pada kertas saring dilakukan dengan X-ray diffractometer tipe XRD-7000 Maxima Shimadzu. Morfologi dan analisa komposisi kimia residu yang tertahan pada kertas saring dilakukan dengan SEM-EDS tipe JEOL JD 2200.

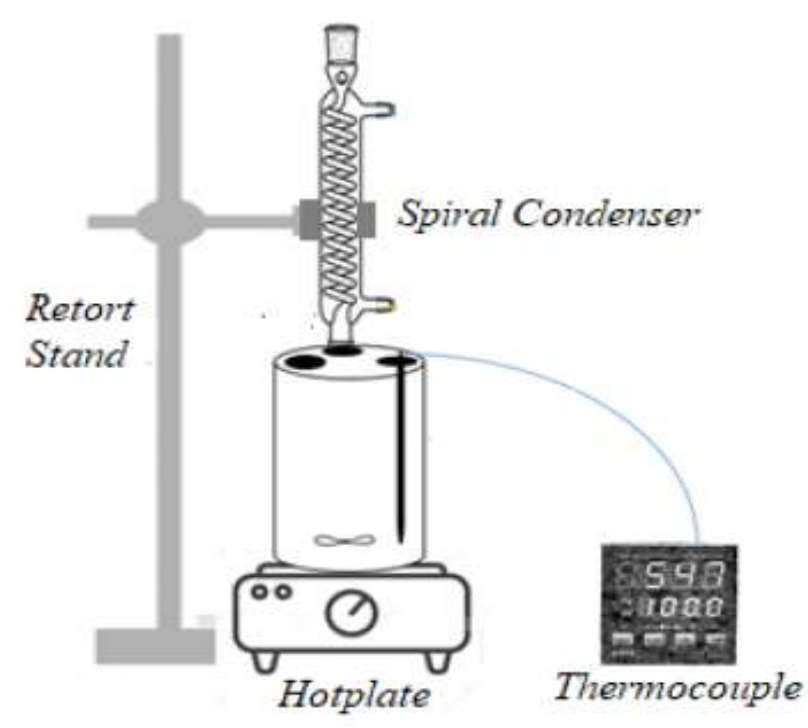

Gambar 1. Skema alat proses pelindian

\section{Hasil dan Pembahasan}

Pelindian dilakukan untuk mengetahui pengaruh jumlah penggunaan $\mathrm{PbO}_{2}$ terhadap persen ekstraksi timbal dan logam pengotornya. Hal ini menjadi penting untuk diketahui pengaruhnya mengingat penambahan $\mathrm{PbO}_{2}$ ditujukan untuk menekan konsumsi penggunaan reagen. Perhitungan jumlah $\mathrm{PbO}_{2}$ didasari dari perhitungan stoikiometri. Pada percobaan ini dilakukan proses pelindian dengan parameter tetap jumlah reagen pelindi dan oksidator hidrogen peroksida sebanyak 2 kali basis perhitungan stoikiometri, temperatur pelindian $97^{\circ} \mathrm{C}$, fraksi ukuran partikel umpan menggunakan -200+325\# dan kecepatan agitasi 300 rpm. Penambahan $\mathrm{PbO}_{2}$ divariasikan pada basis tanpa penambahan yaitu 0,5 kali stoikiommetri, 1 kali stoikiometri, 1,5 kali stoikiometri, dan 2 kali stoikiometri. Hasil perhitungan persen ekstraksi dan selektivitas pelindi disajikan pada Tabel 1. Pelindian tanpa menggunakan penambahan $\mathrm{PbO}_{2}$ menghasilkan filtrat dengan persen ekstraksi timbal sebesar $66,8 \%$ pada waktu sampling menit ke-35. Namun terjadi penurunan persen ekstraksi timbal menjadi 52,9\% pada akhir pelindian. Penurunan persen ekstraksi ini diakibatkan terbentuknya endapan $\mathrm{PbSO}_{4}$ selama proses pelindian yang menyebabkan logam timbal mengendap sebagai residu [10].

Tabel 1. Hasil perhitungan \%ekstraksi dan selektivitas pelindian

\begin{tabular}{ccccccc}
\hline \multirow{2}{*}{ Jumlah $\mathrm{PbO}_{2}$} & \multirow{2}{*}{ Waktu } & \multicolumn{3}{c}{ \%Ekstraksi } & \multicolumn{2}{c}{ Selektivitas } \\
\cline { 2 - 6 } & 5 & $\mathrm{~Pb}$ & $\mathrm{Zn}$ & $\mathrm{Fe}$ & $\mathrm{Pb} / \mathrm{Zn}$ & $\mathrm{Pb} / \mathrm{Fe}$ \\
\hline & 15 & 46,38 & 33,68 & 6,38 & 0,533 & 0,858 \\
& 25 & 52,85 & 40,76 & 6,41 & 0,533 & 0,879 \\
Tanpa $\mathrm{PbO}_{2}$ & 35 & 66,08 & 40,97 & 6,44 & 0,569 & 0,891 \\
& 75 & 63,46 & 37,17 & 5,92 & 0,619 & 0,918 \\
& 135 & 59,06 & 35,50 & 12,84 & 0,61 & 0,902 \\
& 150 & 52,91 & 32,72 & 13,39 & 0,618 & 0,821 \\
& & & & & & 0,798 \\
\hline
\end{tabular}




\begin{tabular}{|c|c|c|c|c|c|c|}
\hline \multirow{7}{*}{$0,5 \times$ stoikiometri } & 5 & 38,29 & 30,88 & 5,83 & 0,554 & 0,868 \\
\hline & 15 & 45,38 & 38,83 & 5,87 & 0,539 & 0,885 \\
\hline & 25 & 54,13 & 36,91 & 6,02 & 0,595 & 0,900 \\
\hline & 35 & 61,49 & 34,84 & 5,87 & 0,638 & 0,913 \\
\hline & 75 & 66,43 & 33,92 & 6,64 & 0,662 & 0,909 \\
\hline & 135 & 59,83 & 30,19 & 8,87 & 0,665 & 0,871 \\
\hline & 150 & 54,53 & 27,60 & 9,03 & 0,664 & 0,858 \\
\hline \multirow{7}{*}{$1 \mathrm{x}$ stoikiometri } & 5 & 39,47 & 28,83 & 5,87 & 0,578 & 0,871 \\
\hline & 15 & 49,48 & 37,01 & 6,06 & 0,572 & 0,891 \\
\hline & 25 & 59,13 & 36,58 & 6,35 & 0,618 & 0,903 \\
\hline & 35 & 63,40 & 32,69 & 6,32 & 0,660 & 0,909 \\
\hline & 75 & 62,61 & 28,69 & 6,44 & 0,686 & 0,907 \\
\hline & 135 & 66,68 & 28,13 & 8,30 & 0,703 & 0,889 \\
\hline & 150 & 62,64 & 25,53 & 8,54 & 0,710 & 0,880 \\
\hline \multirow{7}{*}{$1,5 \times$ stoikiometri } & 5 & 43,38 & 31,38 & 5,89 & 0,580 & 0,881 \\
\hline & 15 & 52,68 & 41,71 & 6,44 & 0,558 & 0,891 \\
\hline & 25 & 61,17 & 37,97 & 6,12 & 0,617 & 0,909 \\
\hline & 35 & 63,43 & 33,82 & 5,43 & 0,652 & 0,921 \\
\hline & 75 & 72,26 & 34,05 & 6,63 & 0,680 & 0,916 \\
\hline & 135 & 73,81 & 30,05 & 7,84 & 0,711 & 0,904 \\
\hline & 150 & 69,32 & 31,73 & 9,86 & 0,686 & 0,875 \\
\hline \multirow{7}{*}{$2 \mathrm{x}$ stoikiometri } & 5 & 39,23 & 23,43 & 4,83 & 0,626 & 0,890 \\
\hline & 15 & 44,43 & 33,88 & 5,55 & 0,567 & 0,889 \\
\hline & 25 & 53,24 & 34,14 & 6,25 & 0,609 & 0,895 \\
\hline & 35 & 51,57 & 27,71 & 5,85 & 0,650 & 0,898 \\
\hline & 75 & 61,24 & 29,19 & 6,96 & 0,677 & 0,898 \\
\hline & 135 & 67,53 & 26,90 & 8,08 & 0,715 & 0,893 \\
\hline & 150 & 69,27 & 26,13 & 10,38 & 0,726 & 0,870 \\
\hline
\end{tabular}

Penambahan $\mathrm{PbO}_{2}$ ditujukan sebagai penstabil ion $\mathrm{Pb}^{2+}$ dan pengontrol potensial redoks sehingga mendapatkan persen ekstraksi yang optimum [10]. Penambahan $\mathrm{PbO}_{2}$ dengan jumlah yang divariasikan ternyata tidak meningkatkan persen ekstraksi timbal secara signifikan seperti yang diharapkan. Namun terjadi peningkatan persen ekstraksi pada hasil akhir filtrat pelindian seiring dengan peningkatan jumlah $\mathrm{PbO}_{2}$ yang ditambahkan ke dalam reaktor pelindi. Gambar 2 menunjukkan pengaruh waktu pelindian pada setiap variasi penggunaan $\mathrm{PbO}_{2}$ terhadap persen ekstraksi timbal. Berdasarkan hasil tersebut ditunjukkan bahwa pelindian dengan atau tanpa penggunaan $\mathrm{PbO}_{2}$ dengan rasio di bawah 2 kali stoikiometri terjadi penurunan persen ekstraksi timbal pada akhir pelindian. Persen ekstraksi timbal tanpa penggunaan $\mathrm{PbO}_{2}$ terlihat menurun setelah menit ke-35. Sedangkan penurunan pada pelindian dengan penggunaan $\mathrm{PbO}_{2}$ terjadi setelah menit ke-75. Hal ini menunjukkan bahwa $\mathrm{PbO}_{2}$ menstabilkan ion $\mathrm{Pb}^{2+}$ ataupun mengontrol potensial reaksi sehingga mencegah pembentukan endapan timbal sulfat.

Pada pelindian dengan penggunaan $\mathrm{PbO}_{2}$ rasio setengah kali stoikimetri, penurunan persen ekstraksi terjadi setelah menit ke-75, sedangkan penggunaan satu kali stoikiometri, penurunan terjadi setelah menit ke-135. Pengaruh jumlah penggunaan $\mathrm{PbO}_{2}$ terhadap penurunan persen ekstraksi tersebut menjelaskan bahwa semakin banyak jumlah $\mathrm{PbO}_{2}$ yang digunakan, amak akan semakin stabil ion $\mathrm{Pb}^{2+}$ sehingga memudahkan logam timbal untuk larut ke dalam larutan filtrat pelindian. 
Penambahan $\mathrm{PbO}_{2}$ ternyata dapat menekan laju kelarutan logam pengotor selain timbal. Hasil kalkulasi selektivitas pelindian menunjukkan bahwa pelindian tanpa penambahan $\mathrm{PbO}_{2}$, selektivitas pelindian timbal terhadap seng dan besi berturut-turut adalah 0,617 dan 0,798. Penambahan $\mathrm{PbO}_{2}$ sebanyak 0,5 kali stoikiometri dapat meningkatkan selektivitas pelindian timbal terhadap seng sebesar 0,655 dan 0,853 untuk logam timbal terhadap besi.

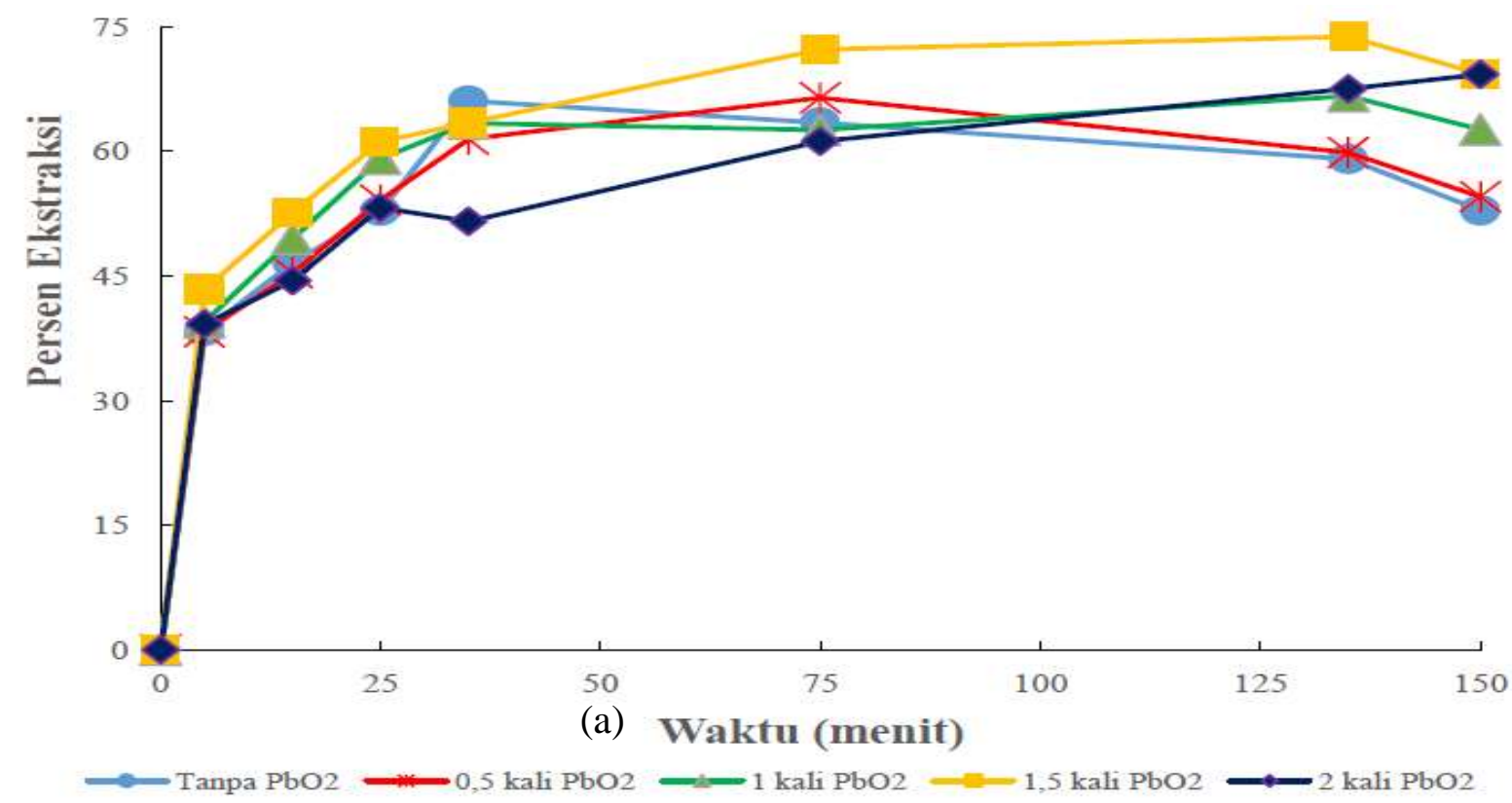

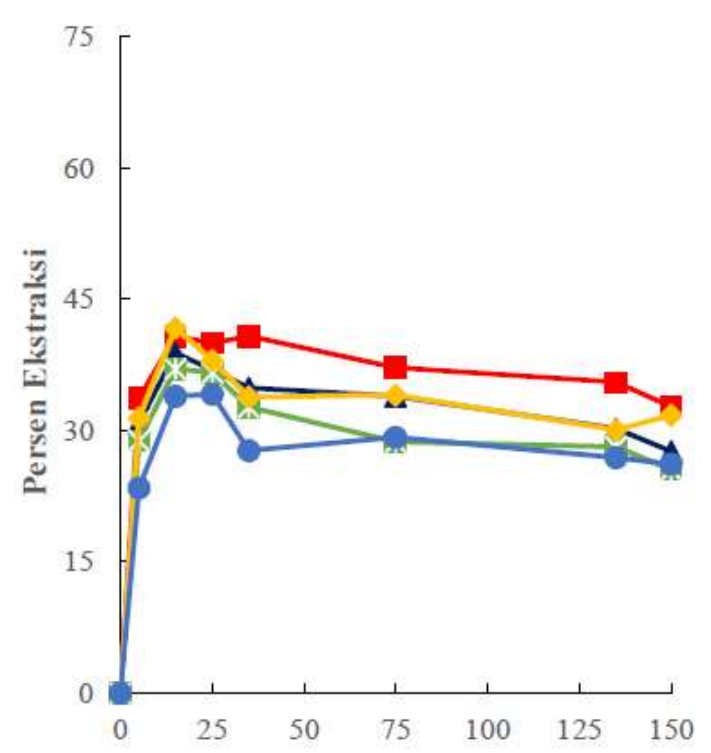

(b) Waktu (menit)

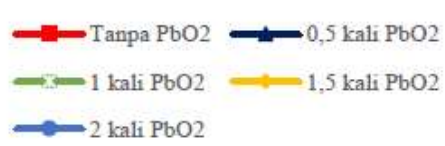

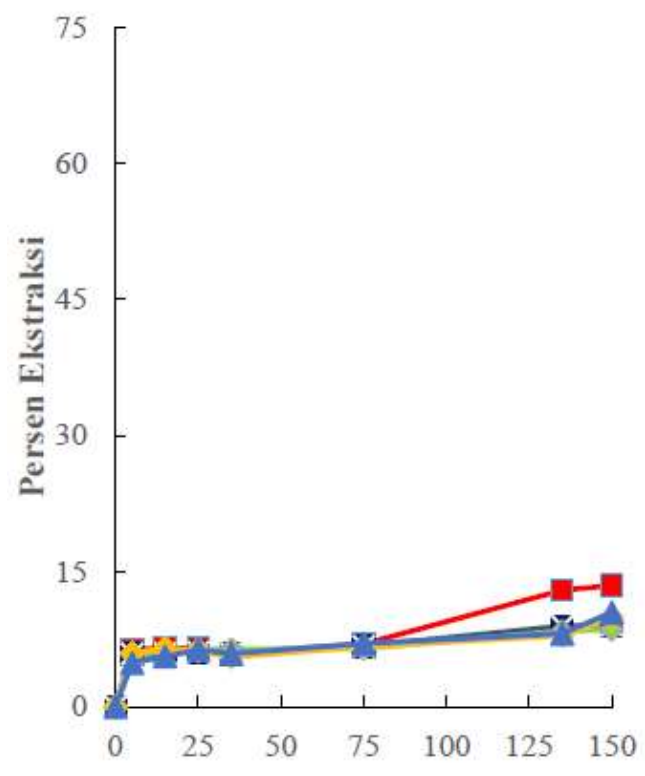

(c) Waktu ( menit)

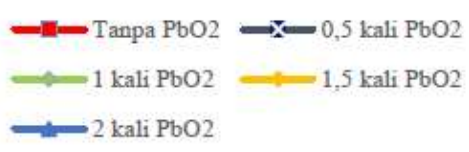

Gambar 2. Grafik persen ekstraksi (a) timbal (b) seng (c) besi terhadap waktu pelindian menurut variasi penggunaan $\mathrm{PbO}_{2}$. 
Merujuk pada setiap hasil pelindian, mayoritas persen ekstraksi timbal yang diperoleh adalah di bawah 75\%. Rendahnya persen ekstraksi ini diduga bahwa penambahan $\mathrm{PbO}_{2}$ secara berkala pada setiap 15 menit, menyebabkan tingginya nilai potensial redoks, sehingga mencapai daerah pembentukan $\mathrm{PbSO}_{4}$. Proses pelindian galena yang optimal diharapkan membentuk ion $\mathrm{Pb}^{2+}$ dan sulfur elemental sehingga ion $\mathrm{Pb}^{2+}$ akan berikatan dengan $\mathrm{SiF}_{6}^{2-}$ membentuk $\mathrm{PbSiF}_{6}$ dalam fasa larutan kaya timbal [8]. Parameter fenomena ini apabila merujuk pada diagram Pourbaix adalah pada kondisi $\mathrm{pH}$ dengan nilai di bawah 1 dengan nilai potensial redoks sebesar 430-580 mV [11].

Penambahan oksidator yang berlebihan menyebabkan suasana yang terlalu oksidatif dalam media pelindi yang ditunjukkan dengan tingginya angka potensial redoks. Hal ini menyebabkan terbentuknya $\mathrm{PbSO}_{4}$ dalam larutan pelindi. Suasana oksidatif yang berlebih mengakibatkan sulfur yang terikat pada mineral sulfida teroksidasi menjadi ion $\mathrm{SO}_{4}^{-}$yang bereaksi dengan ion $\mathrm{Pb}^{2+}$ sehingga terbentuk $\mathrm{PbSO}_{4}$ yang mengendap pada residu pelindian [11].

Penambahan $\mathrm{PbO}_{2}$ pada sistem pelindian tanpa menggunakan instrumentasi yang mengukur nilai potensial sistem dapat menyebabkan potensial suatu sistem terlalu tinggi, sehingga mencapai daerah pembentukan senyawa yang tidak diharapkan dalam proses pelindian. Pada pelindian ini, dapat dilihat bahwa, apabila potensial redoks melewati nilai di atas $580 \mathrm{mV}$ (pendekatan), pada sistem $\mathrm{pH}$ di bawah 1, maka mengacu pada diagram Pourbaix dapat diprediksi produk dominan hasil pelindian adalah $\mathrm{PbSO}_{4}$ yang bersifat tidak larut ataupun menjadi endapan pada sistem flosilikat sehingga timbal tidak terdeteksi dengan optimum. Pernyataan tersebut didukung oleh hasil karakterisasi residu dengan menggunakan XRD dan fotomikrografi SEM yang disajikan pada Gambar 3 dan 4. Pada setiap residu produk pelindian yang dikarakterisasi, menunjukkan bahwa senyawa dominan yang terdapat pada residu adalah anglesite $\left(\mathrm{PbSO}_{4}\right)$.

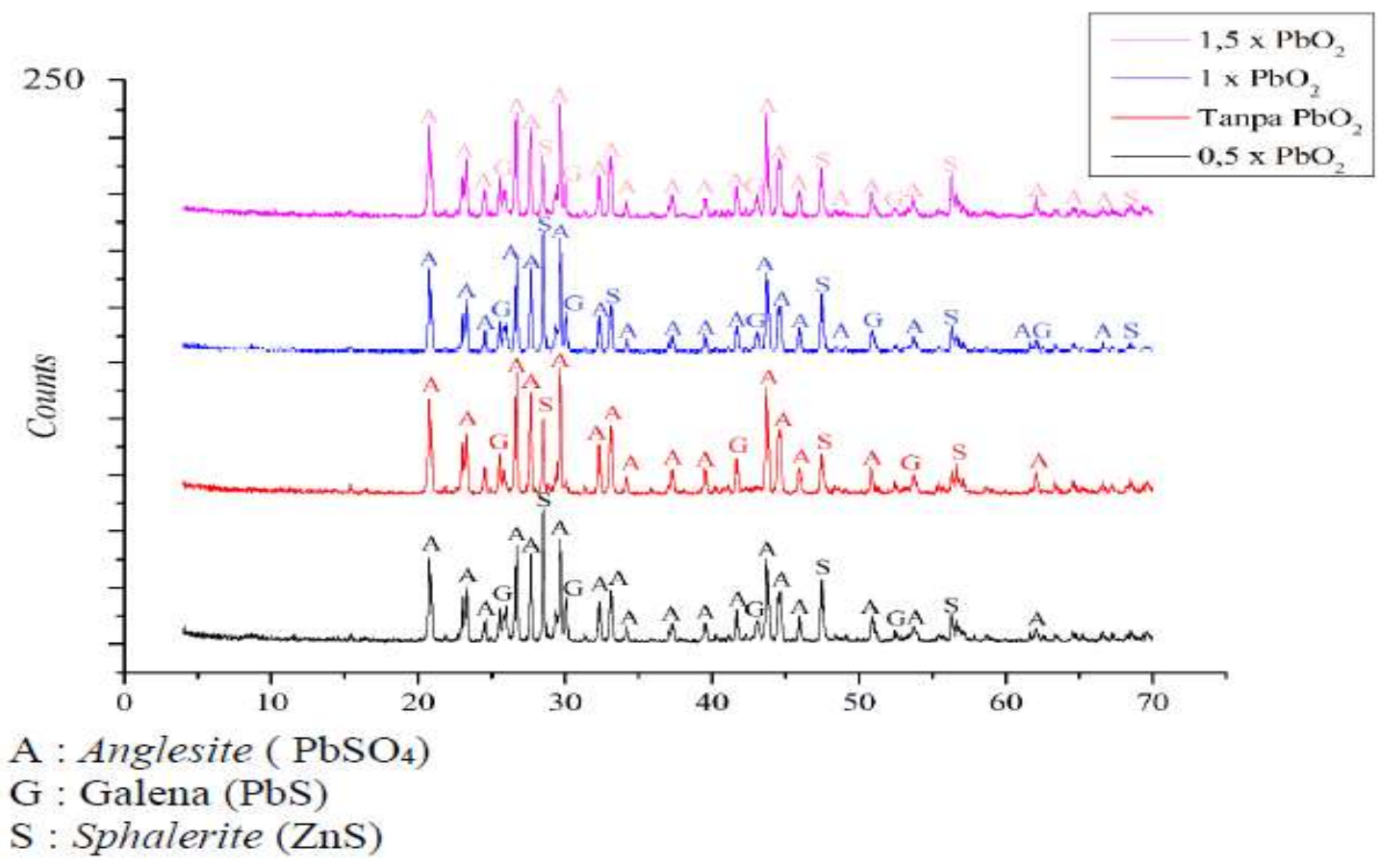

Gambar 3. Hasil karakterisasi senyawa menggunakan XRD pada residu pelindian galena variasi penambahan $\mathrm{PbO}_{2}$

Percobaan dengan menggunakan variasi penggunaan $\mathrm{PbO}_{2}$ pada proses pelindian ternyata tidak meningkatkan persen ekstraksi timbal secara signifikan. Terlihat bahwa hasil yang paling baik diperoleh pada penambahan $\mathrm{PbO}_{2}$ sebanyak 1,5 kali stoikiometri dengan pelindian selama 135 menit yang berhasil mengekstraksi timbal dalam galena sebesar 73,81\%. Persen ekstraksi timbal ini kemungkinan besar disebabkan oleh jarak penambahan $\mathrm{PbO}_{2}$ yang terlalu dekat yaitu 
selama 15 menit sekali. Menurut Lee dkk, penambahan $\mathrm{PbO}_{2}$ dapat mencegah pembentukan $\mathrm{PbSO}_{4}$ apabila ditambahkan di akhir sebelum proses pelindian berakhir [8].

Analisa pada permukaan residu dan penentuan unsur yang terkandung dalam residu pelindian galena dilakukan dengan menggunakan SEM-EDS. Gambar 3 menunjukkan fotomikrografi SEM permukaan residu dengan variasi penggunaan $\mathrm{PbO}_{2}$ sebesar 1,5 kali stoikiometri. Unsur yang dominan sesuai dengan karakterisasi EDS adalah $\mathrm{Pb}, \mathrm{Cu}, \mathrm{Fe}$, dan $\mathrm{Zn}$ dengan persen berat yang tercantum pada Tabel 2 .

Tabel 2. Komposisi kimia unsur dan senyawa yang terkandung dalam residu pelindian galena 1,5 kali stoikiometri $\mathrm{PbO}_{2}$ menurut hasil SEM-EDS

\begin{tabular}{cccc}
\hline \multicolumn{2}{c}{ Unsur } & \multicolumn{2}{c}{ Senyawa } \\
\hline Rumus & \%Berat & Rumus & \% Berat \\
\hline $\mathrm{O}$ & 34,91 & $\mathrm{SO}_{3}$ & 45,12 \\
$\mathrm{~S}$ & 18,07 & $\mathrm{FeO}$ & 8,02 \\
$\mathrm{Fe}$ & 6,23 & $\mathrm{CuO}$ & 10,22 \\
$\mathrm{Cu}$ & 8,17 & $\mathrm{ZnO}$ & 11,17 \\
$\mathrm{Zn}$ & 8,97 & $\mathrm{PbO}$ & 24,47 \\
$\mathrm{~Pb}$ & 23,65 & & \\
\hline Total & 100 & Total & 100 \\
\hline
\end{tabular}

Permukaan residu didominasi oleh $\mathrm{Pb}$ dan $\mathrm{S}$ yang dapat dikorelasikan pada senyawa $\mathrm{PbS}$ dan $\mathrm{PbSO}_{4}$ sesuai dengan hasil karakterisasi senyawa. Sulfur elemental tidak terbentuk dalam proses pelindian ini yang didukung oleh hasil karakterisasi XRD yang menunjukkan tidak terdapatnya peak Sulfur pada residu pelindian.

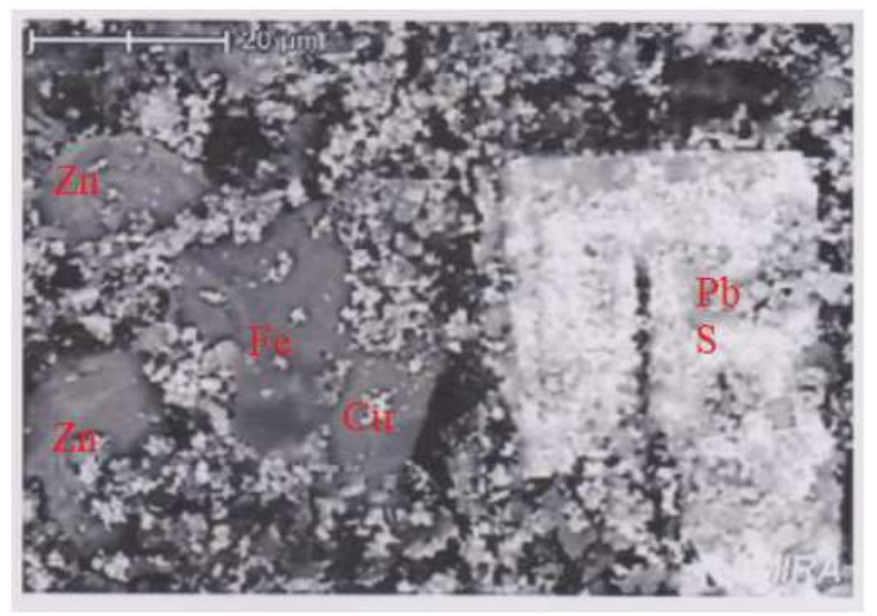

Gambar 4. Fotomikrograf SEM permukaan residu pelindian galena dengan variasi penggunaan $\mathrm{PbO}_{2}$ sebanyak 1,5 kali stoikiometri perbesaran $20 \square \mathrm{m}$.

\section{Kesimpulan}

Berdasarkan hasil penelitian optimasi proses pelindian oksidatif galena dengan penggunaan $\mathrm{PbO}_{2}$ sebagai oksidator, maka dapat disimpulkan bahwa penggunaan $\mathrm{PbO}_{2}$ pada pelindian galena berperan sebagai penstabil ion $\mathrm{Pb}^{2+}$ sehingga dapat meningkatkan persentase ekstraksi hingga 89,79\% pada penggunaan $\mathrm{PbO}_{2}$ sebanyak basis 1,5 kali stoikiometri. Penggunaan $\mathrm{PbO}_{2}$ ternyata belum mampu menekan konsumsi reagen di bawah 3 kali stoikiometri. Penggunaan $\mathrm{PbO}_{2}$ dalam pelindian oksidatif galena pada media asam flosilikat dapat menekan laju kelarutan logam pengotor yang larut pada filtrat produk pelindian. 


\section{Referensi}

[1] Habashi, F., 1997, Handbook of Extractive Metallurgy, vol. 2, hal. 737-752.

[2] Badan Pusat Statistik, 2016, Export-Import Lead BPS Datasheet, Badan Pusat Statistik, Jakarta.

[3] Kementerian ESDM, 2015, Indonesia Mineral and Coal Information 2015, Direktorat Jenderal Mineral dan Coal, hal 37.

[4] Ristiana, R., 2013, Sistem Monitoring Gas $\mathrm{SO}_{2}$ pada Proses Pengolahan Bijih Galena, hal. 141-145.

[5] Taufiq, F.M., T. Padmi, dan D.B. Rahardyan, 2016, Life Cycle Assessment of Dairy Farms, Review Environmental Health, vol. 31, no. 1, hal. 187-190.

[6] WHO, 2016, Uses Lead-Acid Battereies.

[7] Nava, J.L., M.T. Oropeza, dan I. Goza, 2002, Electrochemical Characterisation of Sulfur Species Formed During Anodic Dissolution of Galena Concentrate in Perchlorate Medium at $\mathrm{pH}$ 0, vol 47, hal. 1513-1525.

[8] Lee, A., 1986, Hydrometallurgical Process for Producing Lead and Elemental Sulfur from Galena Concentrates.

[9] Amalia, D. dan Y. Ramanda, 2017, Extraction of Lead From Galena Concentrates Using Fluosilicic Acid and Peroxide, vol. 20, no. 1, hal. 69-80.

[10] Anugrah, R.I., M.Z. Mubarok, dan D. Amalia, 2017, Study on the Leaching Behavior of Galena Concentrate in Fluosilicic Acid Solution Using Hydrogen Peroxide as Oxidant, vol. 30006, hal. 30006, doi: 10.1063/1.4974417.

[11] Brodie, J.B., 1969, The Electrochemical of Galena, British Colombia University. 